\title{
Iconic photographs and the ebb and flow of empathic response to humanitarian disasters
}

\author{
Paul Slovic ${ }^{\mathrm{a}, \mathrm{b}, 1}$, Daniel Västfjäll ${ }^{\mathrm{a}, \mathrm{c}}$, Arvid Erlandsson ${ }^{\mathrm{c}, \mathrm{d}}$, and Robin Gregory ${ }^{\mathrm{a}, \mathrm{e}}$

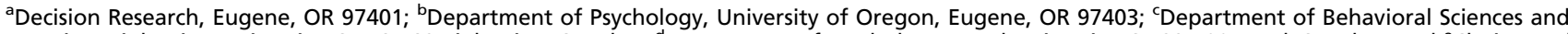

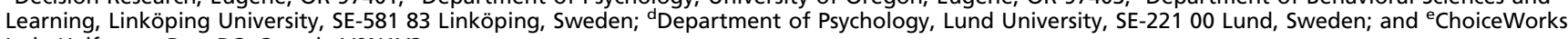 \\ Ltd., Halfmoon Bay, BC, Canada V0N1Y2
}

This contribution is part of the special series of Inaugural Articles by members of the National Academy of Sciences elected in 2016.

Contributed by Paul Slovic, December 8, 2016 (sent for review August 22, 2016; reviewed by Robin M. Hogarth and Eldar Shafir)

The power of visual imagery is well known, enshrined in such familiar sayings as "seeing is believing" and "a picture is worth a thousand words." Iconic photos stir our emotions and transform our perspectives about life and the world in which we live. On September 2, 2015, photographs of a young Syrian child, Aylan Kurdi, lying face-down on a Turkish beach, filled the front pages of newspapers worldwide. These images brought much-needed attention to the Syrian war that had resulted in hundreds of thousands of deaths and created millions of refugees. Here we present behavioral data demonstrating that, in this case, an iconic photo of a single child had more impact than statistical reports of hundreds of thousands of deaths. People who had been unmoved by the relentlessly rising death toll in Syria suddenly appeared to care much more after having seen Aylan's photograph; however, this newly created empathy waned rather quickly. We briefly examine the psychological processes underlying these findings, discuss some of their policy implications, and reflect on the lessons they provide about the challenges to effective intervention in the face of mass threats to human well-being.

empathy | iconic photographs | humanitarian disasters | psychic numbing | Syrian refugees

n June 2016, 51 US State Department officials who had been involved in the US government's response to the Syria crisis during the past $5 \mathrm{y}$ sent a message to their Director of Policy Planning. The message was remarkable in its angry and strongly worded dissent toward the Obama administration's policies of restraint, especially because it was drafted and signed by so many individuals who had been party to the creation of those policies.

The dissenting document implored the Obama administration to use military force to compel the Syrian regime to cease its attacks on civilians and negotiate a political solution to a crisis that has left "over 400,000 people dead, hundreds of thousands still at risk from regime sieges, and 12 million people from a population of 23 million displaced from their homes" (1). The dissenters concluded that "the moral rationale for taking steps to end the deaths and suffering in Syria, after five years of brutal war, is evident and unquestionable."

What is also remarkable is that, during the relentless and wellpublicized buildup of casualties and displaced persons over this 5-y period, it took so long for these gruesome statistics to motivate a public call by top-level government officials for aggressive action against the Syrian regime. This is a dramatic testament to the inability of statistics to convey the meaning of mass atrocities and impact policy. Psychological research helps explain this statistical impotency and the powerful but fleeting success of one iconic image in sensitizing the world to the grim realities beneath the surface of the numbers.

\section{Imagery, Emotion, and Meaning}

The power of visual imagery is well known, enshrined in such familiar sayings as "seeing is believing" and "a picture is worth a thousand words." Iconic photos stir our emotions and transform our perspectives about life and the world in which we live. Who has not seen and been moved by such images as the mushroom cloud, the young Vietnamese girl fleeing naked from a napalm bombing, the Chinese man facing down a column of tanks in Tiananmen Square, the view of earth from space, and the jetliner flying into the World Trade Center? Psychological research confirms the greater impact of images over statistics, even when the amount of exposure is roughly equal (2-5).

More recently, on September 2, 2015, another striking photograph joined the list. A photograph of a young Syrian child, Aylan Kurdi, lying face-down on a Turkish beach, was viewed by more than 20 million people on social media (6) (Fig. 1). (The boy's name was Alan Shenu, however we have chosen to use the name given by Turkish authorities and publicized in media reports, Aylan Kurdi.) The next day, the photo was on the front pages of newspapers worldwide. This photograph brought muchneeded attention to the Syrian war and the plight of its refugees, which resulted in short-term but important increases in individual aid and refugee policy changes in many countries (6). However, the Syrian crisis had been ongoing for more than $4 \mathrm{y}$ before Aylan's death. During that time, sources such as the Syrian Observatory for Human Rights had been regularly releasing updates on the steadily rising death toll, conservatively estimated at 250,000 at the time of publication of Aylan's photo. Clearly, the statistics of a massive human catastrophe and their "moral rationale" were available for people and governments to act on, but little response was evident.

New behavioral data from information searches and donations demonstrates that, in this case, an iconic photo of a single child was worth more than hundreds of thousands of statistical lives. People who were unmoved by the relentlessly rising death toll in Syria appeared to care much more about the crisis there after

\section{Significance}

We cannot assume that the statistics of mass human crises will capture our attention or move us to take action, no matter how large the numbers. The data that we present show that the world was basically asleep as the body count in the Syrian war rose steadily into the hundreds of thousands. The iconic image of a young Syrian child, lying face-down on a beach, woke the world for a brief time, bringing much-needed attention to the war and the plight of its many victims. But this empathic response was short-lived. We outline the need for better laws, institutions, and decision-making procedures to channel empathy into appropriate and effective humanitarian actions by individuals and their governments.

Author contributions: P.S., D.V., and A.E. designed research; P.S., D.V., and A.E. performed research; P.S., D.V., and A.E. analyzed data; and P.S., D.V., A.E., and R.G. wrote the paper. Reviewers: R.M.H., Universitat Pompeu Fabru; and E.S., Princeton University. The authors declare no conflict of interest.

Freely available online through the PNAS open access option.

${ }^{1}$ To whom correspondence should be addressed. Email: pslovic@uoregon.edu. 


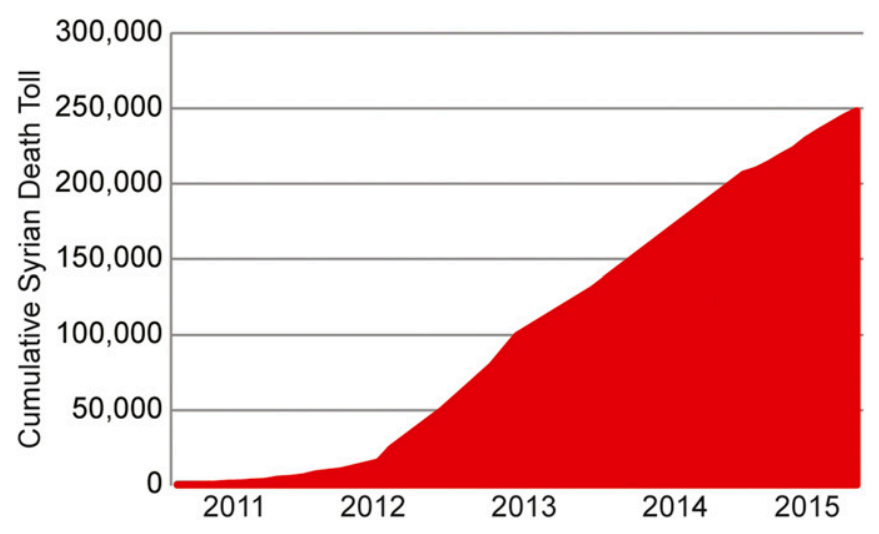

Fig. 1. Cumulative Syrian death toll (data from the Jerusalem Center for Genocide Prevention and the Syrian Observatory for Human Rights).

having seen Aylan's photograph. Here we briefly examine the psychological processes underlying these findings, discuss some of their policy implications, and reflect on the lessons they provide about the challenges to effective intervention in the face of mass threats to human well-being.

We first examined two datasets to assess the effect of the photograph of Aylan Kurdi on the public's interest in and concern about the Syrian refugee crisis. We collected Google trend data on searches worldwide for the terms "Syria," "refugees," and "Aylan" from before (August 2015) and after Aylan's photo was published. Such publicly available data track how often a particular search term is entered relative to the total search volume (7). As can be seen, these data show a dramatic increase in searches for the terms "Aylan," "refugees," and "Syria" on the days after publication of the photo (Fig. 2). These searches declined during the subsequent weeks, but still remained above the August 2015 baseline.

We also obtained data on monetary donations to the Swedish Red Cross for a fund specifically designated to aid Syrian refugees. The funding campaign started on August 4, 2015, almost a month before Aylan's photo appeared, and continued until November 30 , 2015. Thus, we can use these data to estimate the photograph's effect in this specific context.

Fig. 3 shows the number of daily donations to the Red Cross, and Fig. 4 shows the total daily donation amounts during this period (excluding single donations exceeding 1,000,000 SEK). As can be seen, both increased greatly from the week before to the week after the publication of Aylan's photo. The mean number of daily donations during the week after publication of the photo was more than 100 -fold greater compared with the week before. This effect was sustained until $5 \mathrm{wk}$ after the photo's appearance, when the number declined to a level no different from that in the week before publication.

Similarly, the mean amount donated daily during the week after the photo's publication was 55-fold higher compared with the week before $(1,908,437$ SEK vs. 34,284 SEK). During the second week after the photograph appeared, donation amounts were lower $(404,626 \mathrm{SEK})$, but still approximately 11-fold greater than the week before publication. It was not until $6 \mathrm{wk}$ after publication that the mean donations were at a level (57,990 SEK) that was not significantly different from that in the week before publication.

These data illustrate the iconic victim effect. The photograph of a single identified individual captured the attention of people and moved them to take interest and provide aid in ways that were not motivated by statistics of hundreds of thousands of deaths. The data also show that this form of empathy quickly faded and donations subsided, even though the number of Syrian refugees seeking asylum in Sweden was relatively high and consistent throughout the period that we sampled $(36,000-$ 40,000 per month).

Does the iconic victim response diminish rapidly as the image fades from memory and the media lose interest? Judging from the foregoing data, this appears to be the case. Additional data from the Swedish Red Cross are somewhat more encouraging, however. The number of monthly donors signing up for repeated contributions increased by a factor of 10 (from 106 in August 2015 to 1,061 in September 2015), and only $0.02 \%$ of those monthly donors had opted out by January 2016. This suggests that the iconic victim effect may lead not only to large and immediate increases in the number of one-time donors and average donations per person, but also to more prolonged and sustained commitment when individuals sign up for repeated donations.

Nonetheless, close to $1 \mathrm{y}$ after the appearance of Aylan's photo, and despite the publication of other touching images of imperiled refugee children, little seems to have changed $(8,9)$. After a string of boat disasters claimed 2,510 lives between January and May and put year 2016 on course to be the deadliest ever for refugees, Aylan Kurdi's father said that "my Aylan died for nothing" (10). By the end of May 2016, leaders at the World Humanitarian Summit in Istanbul appeared to show little interest in addressing what has been described as the worst humanitarian crisis since World War II, angering many of the aid organizations in attendance (11). In June, the State Department dissenters could no longer keep silent. Other prominent statesmen, diplomats, and journalists have since joined the call for some form of military intervention to stop the relentless slaughter of innocent people in Syria (12-14). Even US Secretary of State John Kerry expressed (privately) dissatisfaction with the administration's lack of forceful response (15).

\section{What Have We Learned from the Story of Aylan?}

One of the important lessons from the story of Aylan is that we cannot assume that the statistics of mass human crises will capture our attention or move us to take action, no matter how large the numbers. Our search data show that the world was basically asleep as the body count in Syria rose steadily into the hundreds of thousands. Perhaps this should not surprise us. A famous saying, sometimes attributed to Josef Stalin, observed that "One man's death is a tragedy, a million deaths is a statistic." Similarly, economist Thomas Schelling (16) wrote that "the death of a particular person evokes anxiety and sentiment, guilt and awe, responsibility and religion...[but] most of this awesomeness disappears when we deal with statistical death" (p. 142).

Psychological research supports these observations. A single individual in distress, with a name and a face, often evokes a

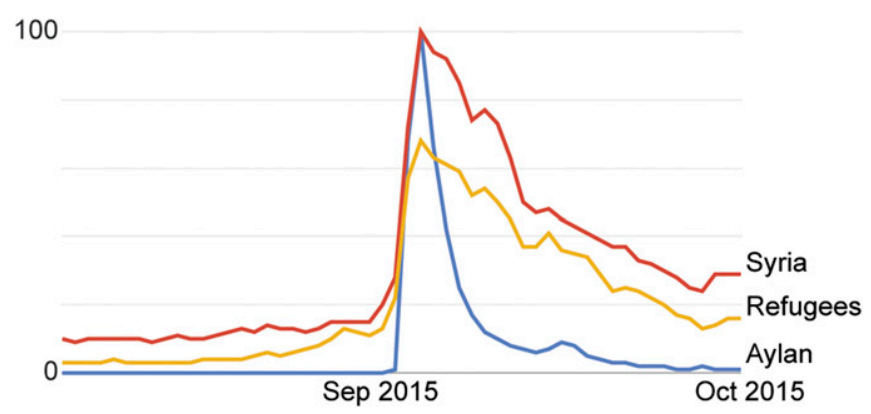

Fig. 2. Google Trend data on the relative popularity of search terms "Syria," "refugees," and "Aylan," August-September 2015. Note that Google Trends does not provide numbers of search requests; rather, the maximum number in the figure is scaled to 100 , and the other values are proportional to that. 


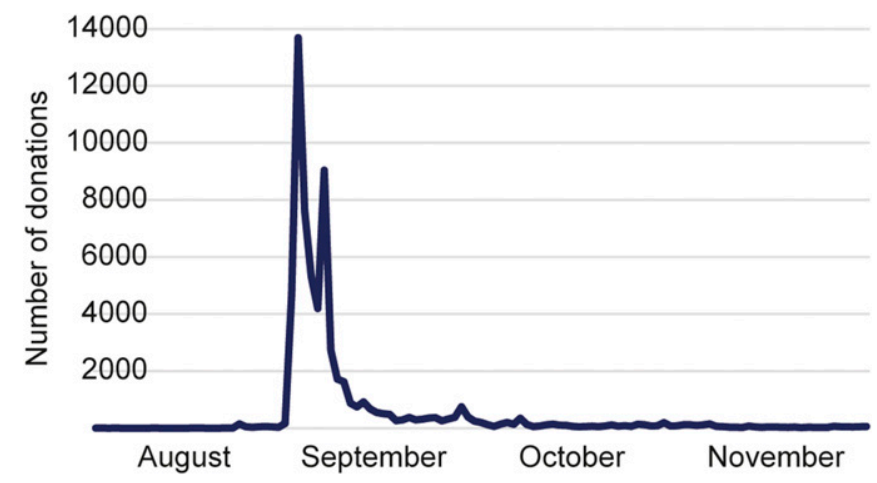

Fig. 3. Number of daily donations to a Swedish Red Cross campaign designated specifically for aiding Syrian refugees in Sweden.

stronger response than multiple persons $(3,17,18)$. We have found that this "compassion fade" may begin when an incident involving a single person expands to as few as two people. In one study (19), participants were asked to make donations and to report how they felt about donating to either a single needy child or two needy children, each of whom was identified with a photograph, name, and age. Positive feelings about donating declined substantially when the group size was two, and this decline in feeling was predictive of lower levels of donation. If we begin to lose feeling and response at two persons, it is no wonder that we experience "psychic numbing" when the numbers reach the thousands $(18,20)$.

Various psychological factors appear to drive psychic numbing and compassion fade. It may be natural and relatively easy to empathize and feel compassion with a single identified individual, but it is difficult to "scale up" this emotion when we need to consider more than one individual. If one feels strongly about one person in distress, the appearance of a second needy individual will not lead to twice the level of emotion. Limitations of imagery and attention also play a role. Research reported by Hamilton and Sherman (21) and Thompson et al. (22) has demonstrated that a single individual, unlike a group, is viewed as a psychologically coherent unit. This leads to more focused attention, more extensive processing of information, and stronger feelings about individuals than about groups. The failure of large numbers to convey images and emotions is well known and documented in research studies and in popular narratives and discourse (ref. 20; www.arithmeticofcompassion.org). Thousands of wrenching photographs, much like statistics, can also quickly leave us numb (23).

Thus, the valuation of human lives not only may be characterized by a decreasing sensitivity as the numbers increase, but may sometimes even show a decline as imagery fades and attention falters. We have described these tendencies as failings in "the arithmetic of compassion" (20). The strong reaction to the image of Aylan coupled with indifference toward the statistics of thousands of lives lost in Syria illustrates this problematic arithmetic.

Recognition of these shortcomings has led some to argue "against empathy" (24). Bloom (24) has pointed out that the problem with empathy is that it is biased in its focus on the single individual and is innumerate in its failure to increase or even be sustained with the growing number of individuals in need.

Nonetheless, we do believe that empathy is a necessary, though not sufficient, condition for action by both individuals and societies. Aylan woke the world briefly, providing a window of opportunity during which people and their governments began paying attention to the Syrian refugee crisis, understood its severity, and were motivated to act. Where there was a need that was relatively easy to fill, such as with donating to the Red Cross, the response was swift and sizeable, at least for a while. Without that empathic response, the donations shown in Fig. 4 likely would have been consistently small. Thus, empathy can create a strong motivation to act. But lacking a political solution to the underlying warfare in Syria, little progress was made in halting the killing or stemming the tide of refugees. This failure to react can be viewed in part as a failure of society to provide compelling action alternatives once empathy is aroused.

\section{Incoherent Values for Lifesaving}

Simply put, the US government does not have an established, coherent policy for preventing and responding to genocide and mass atrocities (25, p. 3).

Given enough time and suffering, the statistics of mass crises may finally gain attention and motivate attempts at intervention, as with the State Department dissent noted earlier. President Obama has certainly seen the statistics from Syria and agonized over them. Strong efforts to protect civilian lives would be consistent with his assertion that "preventing mass atrocities and genocide is a core national security interest and a core moral responsibility of the United States" (26). However, the dissent memo also makes it clear that there are many serious obstacles to intervention that must be weighed against the potential lifesaving benefits. US and Russian relations might well deteriorate and lead to conflict. The military might suffer losses, and aggressive actions might increase the threat of domestic terrorism or hinder attacks against the Islamic State.

Conflicting objectives inevitably arise as challenges to efforts to manage human and environmental crises; as noted by America's United Nations (UN) Ambassador Samantha Power, "you have to take into account the other collateral issues that you're dealing with on the international stage" (27). We are concerned that without a systematic method of analysis that carefully assesses the desired trade-offs among objectives, decisions will reflect a value for protecting human lives that is far lower than intended. This hypothesis is derived from theoretical models of judgment and choice, research on social cognition, and careful reading of official pronouncements. Its centerpiece is the "prominence effect" (28), which describes conditions that lead values revealed by choices to differ systematically from expressed judgments of value. Specifically, choices need to be justified or defended in ways that expressed values do not. Prominent attributes enhance justifiability; thus, the more prominent attributes of a proposed action likely will be weighted more heavily in choice than would be expected based on the decision maker's explicit expressions of the values under consideration.

We argue that the prominence effect may underlie what we see as a disconnect between expressed and revealed values regarding whether or not to act to protect large numbers of civilian lives under attack in foreign countries. Specifically, we

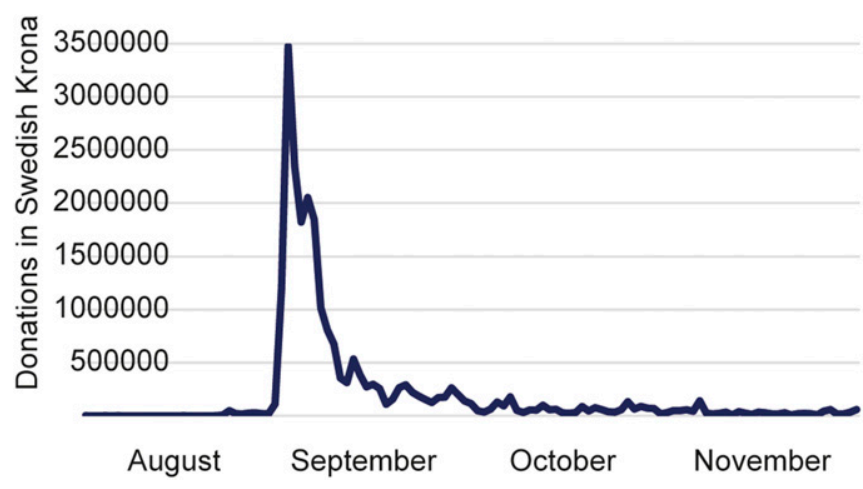

Fig. 4. Daily donation amounts to the Swedish Red Cross campaign. 
hypothesize that national security is the more prominent (i.e., more defensible) dimension in the context that we are studying here. The prominence effect may be amplified by decision makers' response to uncertainty, in that a strong intervention response in Syria will not necessarily succeed and may instead initiate a series of surprising and damaging actions. Because chosen actions need to be justified, deciding in favor of security likely makes a stronger, more defensible argument than deciding in favor of saving foreign lives, even when many thousands or millions of lives are at stake.

\section{Where to Next?}

Ideally, when information in the form of personal stories, dramatic images, or statistical facts wakes us to the necessity to intervene in the mass killing of innocent people, there will be strong international laws and institutions to turn to for support. Unfortunately, however, these do not exist. The Genocide Convention, drafted in 1948, and a recent complementary doctrine, The Responsibility to Protect, have rarely been invoked $(29,30)$. The UN, the institution that should be coordinating interventions, is repeatedly stymied by vetoes from permanent members of the Security Council acting in their own interests. Most recently, Russia vetoed a resolution that would have created a no-fly zone over the besieged city of Aleppo, its fifth veto to block action on Syria before the Council (31).

Lacking UN support, the United States and its allies could decide on their own whether or not to act to protect hundreds of thousands of lives in the face of the conflicting political, social, military, and economic counterarguments noted earlier. Risk/ benefit assessments and trade-offs between lives and security would have to be made. How can we ensure that appropriate decision-making procedures are used and the debates do not bias decisions in favor of achieving prominent objectives that are easier to defend, such as national security, without carefully weighing these against less-prominent or more uncertain objectives, such as human rights or civilian lives?

Perhaps structured decision-aiding processes have been used to inform US policy on humanitarian interventions in Syria. Policy deliberations are not public, but we have seen no evidence of systematic exercises to ensure that all feasible options have been considered and that the objective of protecting human lives has been carefully weighed against security objectives. When observers have been allowed to speak with those privy to the decision deliberations regarding humanitarian interventions in Libya and elsewhere, they report that discussions often took place in an unstructured, ad hoc manner and placed a premium on justifiable arguments for and against action (32).

In the window of opportunity afforded when the likes of Aylan Kurdi help us grasp the importance of the lives beneath the numbers, we must create ways to effectively integrate emotions and slower, more analytic thinking into decision making. Fortunately, a wide range of decision-aiding techniques have evolved to help structure discussions and debate with the goal of highlighting key considerations and-by making relationships among these decision elements more transparent-encouraging participants to pay attention to areas of agreement and disagreement (33-36). Three tools are particularly helpful: objective hierarchies, performance measures, and consequence tables.

Objective hierarchies provide a vehicle for identifying and ordering concerns relevant to a decision (36). For example, key

1. US Department of State (2016) Dissent channel: Syria policy. Available at https:// assets.documentcloud.org/documents/2866467/State-Dept-Dissent-Memo.pdf. Accessed December 28, 2016.

2. Genevsky A, Västfjäll D, Slovic P, Knutson B (2013) Neural underpinnings of the identifiable victim effect: Affect shifts preferences for giving. I Neurosci 33(43): 17188-17196.

3. Kogut T, Ritov I (2005) The "identified victim" effect: An identified group, or just a single individual? J Behav Decis Mak 18(3):157-167. values for intervention decisions to prevent mass atrocities and genocide will typically include effects on national security, protection of human lives, economic costs of intervention and aid, effects on national reputation, and impacts on regional stability. Each of these fundamental concerns often will include several subobjectives; "protecting human lives," for example, includes both deaths and injuries that might affect either foreign civilians or members of the intervening military forces.

Performance measures establish one or more specific metrics that track changes in the objectives related to a proposed action (37). Developing good measures for changes to each interest is essential for the consistent evaluation of alternatives, and also permits clear communication about what matters among the decision participants. Coming up with measures for some objectives is relatively easy-for example, using dollars to measure cost or numbers of fatalities for lives lost. Other important objectives, such as "national security" or "national reputation," are more difficult to define, yet deliberations about intervention options will be improved to the extent that different intervention alternatives can be compared on these dimensions and all stakeholders are using the same working definitions (34).

Consequence tables are another key structuring tool used to emphasize the link between the consequences of actions and the concerns that matter the most (38). Columns show the different intervention alternatives under consideration, and rows show the different values that may be impacted. Each cell of the table thus indicates what is anticipated to occur if that alternative is selected. Consequence tables can be kept simple or can incorporate additional considerations, such as changes in information over time, thresholds signaling the need for possible shifts in actions, or important geographic differences among potentially affected regions.

As noted above, the need to justify highly visible and controversial national policy decisions, such as intervening in a foreign country to prevent genocide, may lead to heavy reliance on the more prominent (i.e., justifiable) dimensions of choice options and result in a disconnect between the stated importance of values and their influence on decisions. This is particularly true when the process of decision making leads other values, such as protecting human lives, to become less prominent as the result of psychic numbing, uncertainty, or other factors. Of course, decision aids cannot make the tough choices required with respect to interventions intended to prevent genocide and mass atrocities, or overcome the rigid perspectives of policy makers whose minds are closed; however, they do have the ability to set out a coherent, transparent process that provides a defensible argument in support of a selected action. Vague doctrines, such as "protect the national interest," or "promote humanitarian interventions," can be translated into clear statements as part of a more fully defined, organized framework that promotes both understanding and discussion of the underlying objectives. Surely, for decisions as difficult and emotionally charged as those highlighted by the photograph of Aylan Kurdi, we should require nothing less.

ACKNOWLEDGMENTS. We thank Andrew Quist and Leisha Wharfield for their assistance with manuscript preparation. This material is based on work supported by the US National Science Foundation (Grants 1227729 and 1427414), the Riksbankens Jubileumsfond, and the Swedish Research Council. Any opinions, findings, and conclusions or recommendations expressed in this material are those of the authors and do not necessarily reflect the views of the National Science Foundation.

4. Lee S, Feeley TH (2016) The identifiable victim effect: A meta-analytic review. Soc Influence 11(3):199-215

5. Small DA, Loewenstein G, Slovic P (2007) Sympathy and callousness: The impact of deliberative thought on donations to identifiable and statistical victims. Organ Behav Hum Decis Process 102(2):143-153.

6. Goriunova O, Vis F, eds (2015) The Iconic Image on Social Media: A Rapid Research Response to the Death of Aylan Kurdi (Visual Social Media Lab, Sheffield, UK). 
7. Hyunyoung C, Varian H (2012) Predicting the present with Google Trends. Econ Rec 88(s1):2-9.

8. Blanchfield M (May 31, 2016) Romeo Dallaire: Rwandan genocide is being repeated right now in Syria. Huffington Post. Available at www.huffingtonpost.ca/2016/05/31/ dallaire-decries-global-inaction-on-syria-amid-rwanda-holocaust-comparisons_n_10221510. html. Accessed December 28, 2016.

9. Hiatt F (April 6, 2016) Obama destroyed Syrians' "glimmer of hope" that America would intervene. Washington Post. Available at https://www.washingtonpost.com/ opinions/obama-destroyed-syrians-glimmer-of-hope-that-america-would-intervene/2016/ 04/06/1dea7e52-fb80-11e5-9140-e61d062438bb story.html. Accessed December 28, 2016.

10. Tonacci $F$ (May 30, 2016) Abdullah Kurdi: II mondo ha pianto il mio Alan. Pio solo parole e muri per chi fugge. Repubblica. Available at www.repubblica.it/esteri/2016/ 05/30/news/l_intervista_abullah_kurdi_la_foto_di_mio_figlio_sulla_spiaggia_di_bodrum_e un_simbolo_eppure_niente_e_cambiato_per_c-140891221\%. Accessed December 28, 2016.

11. Mahmoud $Z$ (May 25, 2016) Syrian NGOs lament "dreadful silence" at humanitarian summit. News Deeply. Available at https:/www.newsdeeply.com/syria/articles/2016/05/ 25/syrian-ngos-lament-dreadful-silence-at-summit. Accessed December 28, 2016.

12. Carter J (September 20, 2016) Jimmy Carter: A first step for Syria? Stop the killing. NY Times. Available at www.nytimes.com/2016/09/21/opinion/jimmy-carter-a-first-step-forsyria-stop-the-killing.html. Accessed December 28, 2016.

13. Kristof $\mathrm{N}$ (August 11, 2016) Obama's worst mistake. NY Times. Available at www. nytimes.com/2016/08/11/opinion/obamas-worst-mistake.html. Accessed December 28 2016.

14. Ross DB, Tabler AJ (August 3, 2016) The case for (finally) bombing Assad. NY Times Available at www.nytimes.com/2016/08/03/opinion/the-case-for-finally-bombing-assad. html? Accessed December 28, 2016.

15. Barnard A (September 30, 2016) Audio reveals what John Kerry told Syrians behind closed doors. NY Times. Available at www.nytimes.com/interactive/2016/09/30/ world/middleeast/john-kerry-syria-audio.html? r=0. Accessed December 28, 2016.

16. Schelling TC (1968) The Life You Save May Be Your Own: Problems in Public Expenditure Analysis, ed Chase SB, Jr (Brookings Institution, Washington, DC), pp 127-176.

17. Jenni KE, Loewenstein G (1997) Explaining the "identifiable victim effect." I Risk Uncertain 14(3):235-257.

18. Slovic P (2007) If I look at the mass I will never act: Psychic numbing and genocide. Judgm Decis Mak 2(2):79-95.

19. Västfjäll D, Slovic P, Mayorga M, Peters E (2014) Compassion fade: Affect and charity are greatest for a single child in need. PLoS One 9(6):e100115.

20. Slovic S, Slovic P (2015) Numbers and Nerves: Information, Emotion, and Meaning in a World of Data (Oregon State Univ Press, Corvallis, OR).
21. Hamilton DL, Sherman SJ (1996) Perceiving persons and groups. Psychol Rev 103(2): 336-355.

22. Thompson DV, Hamilton RW, Rust RT (2005) Feature fatigue: When product capabilities become too much of a good thing. J Mark Res 42(4):431-442.

23. Steidle B, Wallace GS (2007) The Devil Came on Horseback: Bearing Witness to the Genocide in Darfur (PublicAffairs, New York).

24. Bloom P (2016) Against Empathy: The Case for Rational Compassion (Ecco, New York)

25. Albright M, Cohen S (2008) Preventing Genocide: A Blueprint for US Policymakers (United States Holocaust Memorial Museum, Washington, DC).

26. White House (2011) Presidential study directive on mass atrocities. Available at https://www.whitehouse.gov/the-press-office/2011/08/04/presidential-study-directive-massatrocities. Accessed December 28, 2016.

27. Osnos E (2014) In the land of the possible. The New Yorker, December 22/29:90-107

28. Tversky A, Sattath S, Slovic $P$ (1988) Contingent weighting in judgment and choice. Psychol Rev 95(3):371-384.

29. Reeves E (January 30, 2008) Genocide prevention: 60 years of abject failure. Christian Science Monitor. Available at www.csmonitor.com/Commentary/Opinion/2008/0130/ p09s02-coop.html. Accessed December 28, 2016.

30. Brookings Institution (2014) The responsibility to protect hangs in the balance Available at www.responsibilitytoprotect.org/index.php/component/content/article/ 35-r2pcs-topics/5320-brookings-institute-the-responsibility-to-protect-hangs-in-the-balance. Accessed December 28, 2016

31. Van Schack B (2016) 5 and counting: Russia vetoes no-fly zone in the Security Council. Available at https://www.justsecurity.org/33456/5-counting-russia-vetoes-no-fly-zonesecurity-council/. Accessed December 28, 2016

32. Lewis M (2012) Obama's way. Available at www.vanityfair.com/news/2012/10/ michael-lewis-profile-barack-obama. Accessed December 28, 2016.

33. Edwards W, Miles RF, von Winterfeldt D (2007) Advances in Decision Analysis: From Foundations to Applications (Cambridge Univ Press, New York).

34. Gregory R, et al. (2012) Structured Decision Making: A Practical Guide to Environmental Management Choices (Wiley-Blackwell, Chichester, UK).

35. Gregory R, Slovic P (2015) Structuring Intervention Decisions to Prevent Genocide and Mass Atrocities. Working Paper 15-02 (Decision Research, Eugene, OR).

36. Keeney R (1992) Value-Focused Thinking: A Path to Creative Decisionmaking (Harvard Univ Press, Cambridge, MA)

37. Keeney RL, Gregory R (2005) Selecting attributes to measure the achievement of objectives. Oper Res 53:1-11.

38. Hammond JS, Keeney RL, Raiffa H (1999) Smart Choices: A Practical Guide to Making Better Decisions (Harvard Business School Press, Brighton, MA). 